\title{
PENGARUH MOTIVASI DAN KEPUASAN KERJA PEGAWAI TERHADAP KUALITAS LAYANAN ADMINISTRASI AKADEMIK DI FTIK IAIN PALU
}

\author{
Wiwin Mistiani \\ Dosen FTIK IAIN Palu
}

This study aims to determine: 1) The effect of employee work motivation on the quality of academic administration services in FTIK IAIN Palu. 2) The effect of employee job satisfaction on the quality of academic administrative services in FTIK IA IN Palu., 3). Effect of Motivation and Job Satisfaction of employees on the Quality of Academic Administrative Services in FTIK IA IN Palu. This research uses a quantitative approach with questionnaire data collection techniques, questionnaires, interviews, observation, and documentation. While the data analysis technique used is the classic assumption test using normality, multicollinearity, and heteroscedasticity tests. Research Results Show There is a significant influence on the work motivation of administrative employees on the quality of Academic Administration Services by $17.4 \%$. There is a significant effect of Employee Job Satisfaction on Academic Administration Service Quality of $51 \%$, and There is a significant effect of motivation and level of employee job satisfaction the quality of academic administration services is $80.3 \%$.

Keywords: motivation, satisfaction, administrative services

Penelitian ini bertujuan untuk mengetahui: 1) Pengaruh Motivasi kerja pegawai terhadap Kualitas Layanan administrasi akademik di FTIK IAIN Palu., 2) Pengaruh kepuasan kerja pegawai terhadap Kualitas Layanan administrasi akademik di FTIK IAIN Palu., 3). Pengaruh Motivasi dan Kepuasan kerja pegawai terhadap Kualitas Layanan administrasi akademik di FTIK IAIN Palu.Penelitian ini menggunakan pendekatan kuantitatif dengan teknik pengumpulan data angket atau kuesioner, wawancara, observasi, dan dokumentasi. Sedangkan teknik analisis data yang digunakan adalah uji asumsi klasik menggunakan uji normalitas, multikolineritas, dan heteroskedastisitas, serta uji hipotesis menggunakan uji parsial (uji t) dan uji simultan (uji F). Hasil Penelitian Menunjukan bahwa terdapat pengaruh yang signifikan motivasi kerja pegawai administrasi terhadap kualitas Layanan Administrasi Akademik sebesar 17,4 \%., Terdapat pengaruh yang signifikan Kepuasan Kerja Pegawai Terhadap Kualitas Layanan Administrasi Akademik sebesar 51\%, Terdapat pengaruh yang signifikan motivasi dan tingkat kepuasan kerja Pegawai terhadap kualitas layanan administrasi akademik sebesar 80,3\%.

Kata Kunci : Motivasi, Kepuasan, Pegawai Administrasi 


\section{Pendahuluan}

Semakin meningkat kebutuhan masyarakat terhadap pendidikan formal, khususnya pendidikan tinggi, menjadikan perguruan tinggi sebagai sektor strategis yang diharapkan dapat menghasilkan sumber daya manusia yang bermutu. Keadaan persaingan yang cukup kompetitif antar perguruan tinggi menuntut lembaga pendidikan memperhatikan kualitas pendidikan dan kelembagaan sehingga mampu serta unggul dalam persaingan tersebut. Perguruan tinggi termasuk IAIN Palu harus melakukan langkah antisipasi guna menghadapi persaingan yang semakin kompetitif serta bertanggung jawab untuk menggali dan meningkatkan segala aspek pelayanan yang dimiliki termasuk di dalamnya kualitas layanan akademik di ujung tobak dari seluruh aktifitas di IAIN Palu, semakin tinggi kualitas layanan yang diberikanmaka semakin tinggi tingkat kepuasan terhadap layanan tersebut. Jika penguna layanan/mahasiswa puas maka akan meningkatkan loyalitas dan kepercayaan terhadap pergurauan tinggi/ fakultas tersebut, begitu pula jika penguna layanan /mahasiswa tidak puas maka loyalitas dan kepercayaan pun berkurang.

Pelayanan akademik sebagai pusat administrasi perkuliahan mempunyai peran, baik secara langsung maupun tidak langsung, terhadap jalannya proses perkuliahan. Adapun tugas dari pelayanan akademik secara umum yaitu sebagai berikut:

1. Merancang bahan dan rencana kegiatan dan pelayanan administrasi akademik kemahasiswaan dan alumni.

2. Melaksanakan kegiatan pelayanan administrasi akademik dan kemahasiswaan dan alumni.

3. Melakukan pengendalian dan evaluasi kegiatan pelayanan administrasi akademik kemahasiswaan dan alumni.

4. Melakukan tugas-tugas lain yang diberikan oleh atasan. ${ }^{1}$

Tingkat kualitas pelayanan administrasi akademik tidak dapat dinilai berdasarkan sudut pandang pegawai administrasi akan tetapi harus dipandang dari sudut pandang penilaian

${ }^{1}$ Uraian tugas sub. Bagian Akademik Kemahasiswaan Dan Alumni Fakultas Tarbiyah dan Keguruan UIN Raden Intan Lampung, 2016. 
pelanggan/mahasiswa. Kepuasan dari sisi mahasiswa dipandang baik apabila memenuhi apa yang mereka harapkan, sebaliknya pelayanan akan dipersepsikan buruk apabila tidak memenuhi yang mereka harapkan. Untuk mengetahui kualitas pelayanan administrasi maka perlu adanya pengukuran. Menurut Philip Kotler didasarkan pada determinan kualitas yang dapat dirincikan sebagai berikut: Berwujud (Tangibles): penampilan fasilitas fisik, peralatan, personel dan media komunikasi. Daya tanggap (Responsiveness): kemampuan untuk membantu pelanggan dan memberikan jasa dengan cepat atau ketanggapan Kepercayaan atau kehandalan (Reliability): kemampuan untuk melaksanakan pelayanan yang dijanjikan dengan tepat dan terpercaya. Empati (Emphaty): syarat untuk peduli, memberi perhatian pribadi bagi pelanggan. Keyakinan (Assurance): pengetahuan dan kesopanan Petugas serta kemampuan mereka untuk menimbulkan kepercayaan dan keyakinan kepada mahasiswa. $^{2}$

Menurut Zeithaml, Berry menyatakan kualitas layanan dapat dilihat dari sepuluh dimensi, yang pada akhirnya menjadi penentu tingkat kepuasan yaitu:

a. Communication, penggunaan bahasa komunikasi yang bisa dipahami pelanggan atau stakeholders: penjelasan tentang layanan itu sendiri,penjelasan tentang besarnya biaya layanan, penjelasan tentang "trade-offs" antara layanan dengan biaya, dan keyakinan pelanggan atau stakeholders.

b. Credibility, kepercayaan pelanggan atau stakeholders terhadap penyedialayanan: reputasi perusahaan, karakteristik personal yang bisa dikontak,dan derajat interaksi dengan pelanggan atau stakeholders.

c. Security, keamanan pelanggan atau stakeholders, bebas resiko, bahasa, dankeragu-raguan: keamanan secara fisik, keamanan dan kerahasiaan.

d. Knowing the customer, pemahaman penyedia layanan terhadap kebutuhandan harapan: pengetahuan menyangkut

${ }^{2}$ Philip Kotler. Marketing Management.Millennium Edition. (New Jersey: Prentice-Hall International, Inc, 2000 ), 45. 
persyaratan, perhatian secaraindividual, dan pengangkutan terhadap pelanggan atau stakeholders regular.

e. Tangibles, dalam memberi layanan harus ada standar pengukurannya:fasilitas fisik, metode yang digunakan, penampilan penyedia layanan.

f. Reliability, konsistensi penyedia layanan dan kemampuan penyedialayanan dalam memenuhi janji: pelayanan yang sama dari pihakperusahaan terhadap semua pelanggan atau stakeholders, kinerja layanansesuai waktu yang dijanjikan, dan ketepatan waktu kedatangan karyawan.

g. Responsiveness, kemauan dan kesediaan penyedia layanan dalam memberlayanan: menghubungi pelanggan atau stakeholders kembali dengan cepat,pemberian layanan yang cepat, dan kesediaan untuk menerima keluhan.

h. Competence, kemampuan atau keahlian penyedia layanan dalammemberikan layanan: pengetahuan dan keterampilan kontak personal,pengetahuan dan keterampilan personal yang mendukung operasi,dan kemampuan meneliti kapabilitas organisasi.

i. Access, kemampuan pendekatan dan kemudahan penyedia layanan untukbisa dihubungi oleh pelanggan atau stakeholders: layanan dengan mudahdiakses lewat telepon, waktu tunggu layanan tidak lama, jam operasi yangsesuai kebutuhan, dan lokasi fasilitas layanan yang tepat.

j. Courtesy, kesopanan, rasa hormat, perhatian dan keadilan penyedia layananketika berhubungan dengan pelanggan atau stakeholders: perhatterhadap hak-hak pelanggan atau stakeholders, dan front linerberpenampilan ${ }^{3}$

Jasa yang melibatkan tingkat interaksi yang tinggi antara penyedia dan pemakai jasa, Tjiptono menyodorkan lima dimensi pokok yang menentukan kualitas perguruan tinggi, yaitu: a) Reliability (keandalan), yakni kemampuan memberikan pelayanan akademik memberikan pelayanan yang dijanjikan dengan segera atau tepatwaktu, akurat dan memuaskan; b) Responsiveness (daya tanggap), yakni kemauan

${ }^{3}$ Berry, L, and Parasuraman.MarketingService Competing Through Quality. (New York: The Free Press. 2002), 30. 
dan kesediaan para staf akademik untuk membantu para mahasiswa dan memberikan pelayanandengan tanggap. Membiarkan mahasiswa menunggu untuk alasan yangtidak jelas dapat menimbulkan persepsi negatif terhadap kualitas; c) Assurance (kepastian), yakni mencakup pengetahuan, kompetensi,kesopanan, respek terhadap mahasiswa, dan sifat yang dapat dipercayayang dimiliki oleh para staf akademik, bebas dari bahaya; d) Empaty (perhatian), yakni meliputi kemudahan dalam hubungan,komunikasi yang baik, perhatian, dan memahami kebutuhan mahasiswa; e) Tangibles (bukti langsung), yakni meliputi fasilitas fisik, perlengkapan,karyawan atau dosen, dan sarana komunikasi di akademik. ${ }^{4}$

Namun pada kenyataannya realisasi pelaksanaan layanan administrasi akademik di FTIK IAIN Palu masih terdapat kesenjangan antara harapan mahasiswa dan kondisi aslinya. Berdasarkan hasil observasi dan wawancara peneliti dengan mahasiswa diperoleh data sebagai berikut: pegawai administrasi tidak selalu berada di loket layanan ketika dimintai layanan, layanan terkesan lambat, tidak adanya kotak saran untuk menjaring keluhan dan saran dari mahasiswa, serta pegawai administrasi terkesan kurang ramah dalam memberikan pelayanan.

Banyak faktor yang mempengaruhi kualitas pelayanan administrasi akademik di FTIK IAIN Palu. Faktor yang pertama yang memiliki pengaruh yang sangat besar terhadap kualitas pelayanan pegawai administrasi adalah motivasi kerja. Moch. As'ad mengistilahkan motivasi sebagai dorongan yang mengerakan jiwa dan jasmani untuk berbuat, sehingga motivasi sering disebut juga driving force yang menggerakkan manusia untuk bertingkah laku dan di dalam perbuatannya itu mempunyai tujuan tertentu. ${ }^{5}$ Sementara itu, Terry dan Rue dalam Suharto dan Budi Cahyono menambahkan bahwa yang dimaksud dengan motivasi adalah "getting a person to exert a

4 Fandy Tjiptono, Perpektif Manajemen dan Pemasaran Kontemporer, (Yogyakarta: Andi, 2000), 42.

${ }^{5}$ Moch As'ad. Psikologi industri (Yogyakarta: libery, 2003), 45. 
high degree of effort..." yang artinya adalah "motivasi membuat seseorang untuk bekerja lebih berprestasi", dengan demikian motivasi merupakan langkah awal seseorang melakukan tindakan akibat kekurangan secara fisik dan psikis atau dengan kata lain adalah suatu dorongan yang ditunjukan untuk memenuhi tujuan tertentu ${ }^{7}$.

Sementara itu, menurut Herzberg ada dua jenis faktor yang mendorong seseorang untuk berusaha mencapai kepuasan dan menjauhkan diri dari ketidakpuasan, yaitu :

1) Maintenance Factor

Adalah faktor-faktor pemeliharaan yang berhubungan dengan hakikat manusia yang ingin memperoleh ketentraman badaniah. Kebutuhan kesehatan ini menurut Herzberg merupakan kebutuhan yang berlangsung terus menerus, karena kebutuhan ini akan kembali pada titik nol setelah dipenuhi. Misalnya orang lapar akan makan, kemudian lapar lagi lalu makan lagi dan seterusnya. Faktor-faktor pemeliharaan ini meliputi hal-hal yang masuk dalam kelompok dissatisfiers seperti gaji, kondisi kerja fisik, kepastian pekerjaan, supervisi yang menyenangkan, kendaraan dinas, rumah dinas dan macammacam tunjangan lainnya.

2) Motivation Factors

Motivation Factors adalah faktor motivasi yang menyangkut kebutuhan psikologis seseorang yaitu perasaan sempurna dalam melakukan pekerjaan. Faktor motivasi ini berhubungan dengan penghargaan terhadap pribadi yang secara langsung berkaitan dengan pekerjaan, misalnya pengakuan, prestasi dan tanggung jawab dan pengembangan diri. ${ }^{8}$

Motivasi kerja yang tinggi sangat diperlukan guna peningkatan mutu pendidikan. Orang yang mempunyai motivasi tinggi akan terpacu untuk bekerja lebih keras dan

${ }^{6}$ Suharto Dan Budi Cahyono, Pengaruh Budaya Organisasi, Kepemimpinan Dan Motivasi Kerja Terhadap Kinerja Sumber Daya Manusia, vol. 1, no.1, (Semarang: Jrbi, 2005), 13.

7 Luthans, Fred., Perilaku organisasi 10th. Edisi indonesia. (Yogyakarta: Penerbit Andi Offiset, 2006), 67.

${ }^{8}$ Hasibuan, Manajemen Sumber Daya Manusia, ed revisi, (Jakarta: bumi aksara, 2008), 109. 
penuh semangat karena mereka melihat pekerjaan bukan sekedar sumber penghasilan tetapi untuk mengembangkan diri dan berbakti untuk orang lain. Oleh karena itu, motivasi penting sebagai dorongan seseorang dalam menghasilkan suatu karya baik bagi diri sendiri maupun bagi kampus. Dengan demikian motivasi mengacu pada dorongan yang baik dari dalam atau dari luar diri seseorang yang mendorong keinginan individu untuk melakukan kegiatan pencapaian tujuan ${ }^{9}$.

Bila motivasi kerja pegawai administrasi rendah maka kualitas layanan yang diberikan oleh pegawai administrasi juga rendah. Karena motivasi kerja sering dikaitkan dengan serangkaian sikap dan nilai-nilai yang mempengaruhi individu untuk mencapai hal spesifik sesuai dengan tujuan individu. Sikap dan nilai tersebut merupakan suatu yang invisible yang memberikan kekuatan untuk mendorong individu bertingkah laku dalam mencapai tujuan. ${ }^{10}$ Motivasi psikologis seperti ingin mendapatkan pengakuan, motivasi beprestasi dan rasa tanggung jawab terhadap pekerjaanya, merupakan faktor-faktor yang dapat memotivasi pegawai administrasi untuk bekerja lebih baik di tempat kerjanya. Pegawai administrasi yang mempunyai motivasi tinggi akan terpacu untuk bekerja lebih keras dan penuh semangat karena mereka melihat pekerjaan bukan sekedar sumber penghasilan tetapi untuk mengembangkan diri dan berbakti untuk orang lain. Oleh karena itu motivasi penting sebagai dorongan seseorang dalam menghasilkan suatu karya baik bagi diri sendiri maupun bagi kampus dimana ia bekerja.

Faktor yang kedua yang sangat berpengaruh terhadap kualitas layanan administrasi yang diberikan oleh pegawai administrasi adalah kepuasan kerja. Setiap orang yang bekerja mengharapkan memperoleh kepuasan dari tempatnya bekerja. Pada dasarnya kepuasan kerja merupakan hal yang bersifat individual karena setiap individu akan memiliki tingkat kepuasan yang berbeda-beda sesuai dengan nilai-nilai yang berlaku dalam diri setiap individu. Semakin banyak aspek

9 Daftt, The Penguin Dictionary Of Psychology, (Ringwood Victoria; Penguin Books Australia ltd, 2002 ), 91

10 Witting, Arno F, Psychology Of Learning, (New York: Mac Grow Hill Book Company 2007), 36. 
dalam pekerjaan yang sesuai dengan keinginan individu, maka semakin tinggi tingkat kepuasan yang dirasakan.

Kepuasan Kerja merupakan sikap (positif) tenaga kerja terhadap pekerjaannya, yang timbul berdasarkan penilaian terhadap situasi kerja. Penilaian tersebut dapat dilakukan terhadap salah satu pekerjaannya, penilaian dilakukan sebagai rasa menghargai dalam mencapai salah satu nilai-nilai penting dalam pekerjaan. Pegawai administrasi yang puas lebih menyukai situasi kerjanya daripada tidak menyukainya. Perasaan-perasaan yang berhubungan dengan kepuasan dan ketidakpuasan kerja cenderung mencerminkan penaksiran dari tenaga kerja tentang pengalaman-pengalaman kerja pada waktu sekarang dan lampau daripada harapan-harapan untuk masa depan. Sehingga dapat disimpulkan bahwa terdapat dua unsur penting dalam kepuasan kerja, yaitu nilai-nilai pekerjaan dan kebutuhan-kebutuhan dasar.

Kepuasan kerja pegawai administrasi merupakan faktor penting dalam upaya peningkatan kinerja pegawai administrasi. Menurut Hasibuan seorang cenderung bekerja dengan penuh semangat apabila kepuasan dapat diperolehnya dari pekerjaan. ${ }^{11}$ Kepuasaan kerja pegawai administrasi merupakan kunci pendorong moral, kedisiplinan, dan prestasi kerja dalam mendukung tujuan kampus. Kepuasaan kerja pegawai administrasi yang baik akan membuat pegawai administrasi semakin termotivasi dan loyal terhadap kampus. Pegawai administrasi yang tidak merasa puas terhadap pekerjaanya seperti ketidakpuasan terhadap gaji dan tunjangan yang diperolehnya, hubungan yang kurang harmonis dengan teman sesama pegawai administrasi dan pimpinan serta tidak meratanya pembagian Job (kerja), tidak memperoleh kesempatan untuk meningkatkan karir di tempat kerja, maka akan cenderung melakukan penarikan atau penghindaran diri dari situasi-situasi pekerjaan baik yang bersifat fisik maupun psikologis.

Artikel ini merupakan hasil penelitian yang dilaksanakan di Institut Agama Islam Negeri (IAIN) Palu,

${ }^{11}$ Hasibuan, Manajemen..., 110 
dengan mengambil fokus pada fakultas Tarbiyah dan Ilmu Keguruan. Fakultas Tarbiyah dan Ilmu Keguruan (FTIK) adalah satu dari tiga fakultas dalam lingkungan Institut Agama Islam Negeri (IAIN) Palu. FTIK sebelumnya adalah Jurusan Tarbiyah yang berada di lingkungan Sekolah Tinggi Agama Islam Negeri (STAIN) Datokarama Palu. Perubahan status STAIN Datorakarama Palu menjadi IAIN Palu berdasarkan Peraturan Presiden RI No. 51 Tahun 2013 dan Peraturan Menteri Agama RI No. 92 Tahun 2013 tentang organisasi dan tata kerja IAIN Palu menjadi landasan didirikannya FTIK.. Lulusan FTIK telah ikut serta mewarnai corak pengembangan sumber daya manusia Indonesia khususnya daerah Sulawesi Tengah. Lulusan tersebut diharapkan menjadi Sarjana Muslim yang ahli dalam bidang kependidikan Islam yang mempunyai kemampuan menerapkan dan mengajarkan ilmu pengetahuan agama Islam berbasis keilmuan dan peradaban Islam klasik, baik melalui pendidikan sekolah maupun pendidikan luar sekolah serta kemampuan merancang konsep-konsep dan manajemen pendidikan Islam.

Hasil penelitian penulis deskripsikan dalam bentuk uraian sebagai berikut:

a. Motivasi Kerja Pegawai FTIK IAIN Palu

Motivasi merupakan dorongan yang mengerakan jiwa dan jasmani untuk berbuat, sehingga motivasi sering disebut juga driving force yang menggerakkan manusia untuk bertingkah laku dan di dalam perbuatannya itu mempunyai tujuan tertentu. Motivasi kerja yang tinggi dari setiap pegawai sangat diperlukan guna peningkatan mutu pendidikan. Indikator motivasi kerja pegawai dinilai berdasarkan Pemberian gaji dan bonus, Supervisi dan arahan dan kebebasan berpendapat, Hubungan dengan atasan dan rekan kerja, kelengkapan fasilitas di tempat kerja, Pekerjaan yang di impikan dan Penghargaan serta Tanggung jawab. Berdasarkan Hasil analisis deskripsi dari 25 reponden yang menjadi obyek penelitian diperoleh informasi bahwa nilai rata-rata (mean) motivasi kerja pegawai sebesar 58,6 dengan standar deviasi 7.69 Nilai tertinggi yang diperoleh sebesar 76, 25 dan nilai terendah 51.25. 
b. Kepuasan Kerja Pegawai Administrasi FTIK IAIN Palu

Kepuasan Kerja merupakan sikap (positif) tenaga kerja terhadap pekerjaannya, yang timbul berdasarkan penilaian terhadap situasi kerja. Penilaian tersebut dapat dilakukan terhadap salah satu pekerjaannya, penilaian dilakukan sebagai rasa menghargai dalam mencapai salah satu nilai-nilai penting dalam pekerjaan. Indikator kepuasan kerja pegawai FTIK IAIN Palu dinilai berdasarkan atas Minat dan kepuasan pada pekerjaan, Ketentraman dalam bekerja, Interaksi dengan pegawai dan atasan, Sikap dan ketrampilan, Pengaturan kerja dan Kondisi kantor tempat kerja. Berdasarkan Hasil analisis deskripsi dari 25 reponden yang menjadi obyek penelitian diperoleh informasi bahwa nilai rata-rata (mean) kepuasan kerja pegawai sebesar 61,76 dengan standar deviasi 3, 39 Nilai tertinggi yang diperoleh sebesar 66,67 dan nilai terendah 57,14 .

c. Kualitas Layanan Administrasi FTIK IAIN Palu

Kottler menyatakan kualitas adalah karakteristik yang menyeluruh dari suatu produk atau pelayanan yang dapat mempengaruhi pada kemampuannyan untuk memuaskan kebutuhan yang dinyatakan atau yang diminta oleh pelanggan atau stakeholders. ${ }^{12}$ Dalam Kumpulan Artikel Hasil Penelitian Bisnis dan Jurnal Strategic menyatakan kualitas jasa atau pelayanan yang ditawarkan perusahaan dapat ditingkatkan melalui perlakuan atas unsur-unsurnya. Lima unsur yang menentukan kualitas jasa, yaitu: tangible, reliability, responsiveness, assurance, dan empathy ${ }^{13}$. Demikian juga pengukuran kualitas layanan administrasi didarkan pada kelima aspek tersebut. Berdasarkan Hasil analisis deskripsi dari 25 reponden yang menjadi obyek penelitian diperoleh informasi bahwa nilai rata-rata (mean) kepuasan kerja pegawai sebesar 76,94 dengan standar deviasi 1,24. Nilai tertinggi yang diperoleh sebesar 98 dan nilai terendah 53,13.

${ }^{12}$ Philip Kottler, Strategis Marketing For Educational Institution, (New Jersey: Prentice-Hall International, Inc, 2000), 49.

${ }^{13}$ Kumpulan Artikel Hasil Penelitian Bisnis dan Jurnal Strategic, Manajemen Bisnis (Berbasis Hasil Penelitian), (Cet; 1, Bandung: Alfabeta, 2007), 156. 
Data yang telah didapatkan penulis kemudian dimasukkan dalam Uji Persyaratan Analisis (Uji Asumsi Klasik), yakni uji normalitas, Uji Multikolinieritas dan Uji Heteroskedastisitas, dengan penjelasan sebagai berikut:

a. Uji Normalitas

Uji normalitas sebagaimana dijelaskan sebelumnya bertujuan untuk mengetahui normal atau tidaknya seuatu distribusi data. Uji Normalitas dilakukan dengan mengunakan uji Kolmogorov-Smirnov dengan bantuan SPSS Versi 16. Taraf signifikansi yang ditetapkan sebesar 0,05 dengan ketentuan jika signifikasi lebih dari 0,05 berarti data normal sedangkan jika signifikansi kurang dari 0,05 berarti data tidak normal. Berdasarkan uji normalitas dengan Kolmogorov-Smirnov $Z$ diperoleh nilai sebesar 0,990 dan Asymp. Sig. sebesar 0,281. Dengan melihat nilai signifikan 0,05 , dimana nilai probabilitas (sig) 0, 281 lebih besar dari signifikan 0,05.

b. Uji Multikolinieritas

Uji multikolinieritas bertujuan untuk menguji ada atau tidaknya korelasi antar variabel independen pada model regresi. Jika korelasi tersebut terjadi, maka terdapat masalah multikolinieritas. Pada model regresi yang baik tidak terjadi korelasi di antara variabel independen. Berdasarkan uji multikolinieritas dengan SPSS diperoleh nilai Vaiance Inflation Factor (VIF) variabel X1 yakni motivasi kerja pegawai sebesar 1.005 dan variable X2 Kepuasan Kerja 1.005 kurang dari 10. Ini menunjukan tidak ada multikolineritas antar variabel independen dalam model regresi.

Sementara itu, hasil perhitungan nilai Tolerance masing-masing variabel menunjukkan variabel X1 yakni motivasi kerja pegawai dan variable X2 Kepuasan Kerja kurang adalah sebesar 0,995. Ini menunjukkan bahwa tidak ada variabel independen yang memiliki nilai Tolerance kurang dari 0,05 (Tolerance <0,05), maka hasilnya tidak terjadi multikolineritas dalam model regresi.

c. Uji Heteroskedastisitas

Uji heteroskedastisitas bertujuan untuk menguji terjadinya ketidaksamaan varians dari residual dalam sebuah regresi pada satu pengamatan ke pengamatan yang lain. Hasil 
analisis menyimpulkan bahwa tidak terjadi heterokedastisitas pada model regresi, sehingga model regresi layak dipakai untuk memprediksi keputusan pemilihan berdasarkan masukan variabel independen (bebas) motivasi dan kepuasan kerja.

Pengaruh pengaruh motivasi kerja terhadap Kualitas Layanan Administrasi A kademik FTIK IAIN Palu

Untuk mengetahui pengaruh motivasi kerja pegawai terhadap kualitas layanan administrasi akademik dilakukan uji parsial dengan menggunakan rumus koefisien product moment dari pearson. Dengan kriteria pengujian: jika $r$ hitung $x$ tabel $=$ Ho ditolak dan jika $\mathrm{r}$ hitung $\mathbb{x}$ tabel $=$ Ho diterima.

Berdasarkan analisis nilai indeks korelasi (rxy) sebesar 0,417. Nilai r tabel product moment yaitu sebesar 0,396 dengan $\mathrm{N}=25$ dan taraf signifikansi yang ditetapkan sebesar 5\% atau 0,05 . Dengan demikian $r$ hitung $=0,417>$ tabel $=0,396$ ini berarti Ho ditolak dan $\mathrm{Ha}$ diterima. Hal ini menunjukkan hipotesis pertama penelitian ini diterima dan terbukti berpengaruh . Adapun kontribusi variabel motivasi kerja pegawai terhadap kualitas layanan administrasi adalah $r^{2} \mathrm{x}$ $100 \%=0,174 \times 100 \%=17,4 \%$. Ini berarti bahwa kontribusi variabel motivasi kerja terhadap kualitas layanan administrasi adalah sebesar $17,4 \%$ dan $82,6 \%$ lainnya ditentukan oleh variabel lain di luar penelitian ini.

Data penelitian yang lain mendeskripsikan bahwa persamaan regresi variable Motivasi Kerja Pegawai $\left(\mathrm{X}_{1}\right)$ dan kualiatas layanan administrasi (Y) dengan konstanta (a) = 37,539 dan $b_{1} X_{1}($ motivasi kerja $)=0,672$ adalah sebagai berikut: $y=a+b_{1} X_{1}=37,539+0,672$. Hal ini menunjukkan jika motivasi kerja meningkat satu satuan maka kualitas layanan administrasi akan mengalami kenaikan pula. Artinya, semakin tinggi motivasi kinerja maka kualitas layanan administrasi akan semakin baik.

Pengaruh Kepuasan Kerja Pegawai terhadap kualitas layanan administrasi akademik FTIK IAIN Palu

Untuk mengetahui pengaruh kepuasan kerja pegawai terhadap kualitas layanan administrasi akademik dilakukan 
uji parsial dengan menggunakan rumus koefisien product moment dari pearson. Dengan kriteria pengujian: jika $r$ hitung $x$ tabel $=$ Ho ditolak dan jika $r$ hitung $<\mathrm{r}$ tabel $=$ Ho diterima . Pengujian tersebut dilakukan dengan menggunakan bantuan program SPSS Versi 16 dan mendapatkan hasil bahwa nilai indeks korelasi (rxy) sebesar 0,714. Nilai $\mathrm{r}$ tabel product moment yaitu sebesar 0,714 dengan $\mathrm{N}=25$ dan taraf signifikansi yang ditetapkan sebesar 5\% atau 0,05. Dengan demikian $\mathrm{r}$ hitung $=0,714>\mathrm{r}$ tabel $=0,396$ ini berarti Ho ditolak dan $\mathrm{Ha}$ diterima. Hal ini menunjukkan hipotesis pertama penelitian ini diterima dan terbukti berpengaruh . Adapun kontribusi variabel kepuasan kerjapegawai terhadap kualitas layanan administrasi adalah $\mathrm{r}^{2} \times 100 \%=0,510 \times 100 \%$ $=51 \%$. Ini berarti bahwa kontribusi variabel kepuasan kerja terhadap kualitas layanan administrasi adalah sebesar 17,4\% dan $82,6 \%$ lainnya ditentukan oleh variabel lain di luar penelitian ini.

Berdasarkan hasil analisis menggambarkan bahwa persamaan regresi variable Kepuasan kerja Pegawai $\left(\mathrm{X}_{2}\right)$ dan kualiatas layanan administrasi (Y) dengan konstanta (a) = 84.538 dan $b_{2} \mathrm{X}_{2}$ (Kepuasan Kerja) $=2.614$ adalah sebagai berikut: $y=a+b_{2} X_{2}=-84.538+0,672$. Hal ini menunjukkan jika kepuasan kerja meningkat satu satuan maka kualitas layanan administrasi akan mengalami kenaikan pula. Artinya, semakin tinggi kepuasan kerja maka kualitas layanan administrasi akan semakin baik.

Pengaruh Kepuasan Kerja dan Motivasi Pegawai terhadap kualitas layanan administrasi akademik FTIK IAIN Palu

Pengujian analisis pengaruh Kepuasan Kerja dan Motivasi Pegawai terhadap kualitas layanan administrasi akademik FTIK IAIN Palu secara simultan terhadap menggunakan analisis korelasi ganda. Analisis ini digunakan untuk menunjukkan arah dan kuatnya hubungan antara dua 
variabel independen secara bersama-sama atau lebih dengan satu variabel dependen. ${ }^{14}$

Pengaruh Kepuasan Kerja dan Motivasi Pegawai terhadap kualitas layanan administrasi akademik FTIK IAIN Palu secara simultan adalah sebesar 0,803 dengan $\mathrm{N}=25$ dan taraf signifikansi yang ditetapkan sebesar $5 \%$ atau 0,05 . Dengan demikian $r$ hitung $=0,803 \times$ tabel $=0,396$ ini berarti Ho ditolak dan Ha diterima. Hal ini menunjukkan hipotesis pertama penelitian ini diterima dan terbukti berpengaruh . Adapun kontribusi variable motivasi dan kepuasan kerja pegawai terhadap kualitas layanan administrasi adalah $r^{2} \mathrm{x}$ $100 \%=0,645 \times 100 \%=64,5 \%$. Ini berarti bahwa kontribusi variable motivasi dan kepuasan kerja terhadap kualitas layanan administrasi adalah sebesar $64,5 \%$ dan $35,5 \%$ lainnya ditentukan oleh variabel lain di luar penelitian ini. Selanjunya untuk melihat signifikan atau tidaknya pengaruh Kepuasan Kerja dan Motivasi Pegawai terhadap kualitas layanan administrasi akademik FTIK IAIN Palu peneliti menguji dengan uji F.

Berdasarkan data yang telah dikumpulkan diperoleh $\mathrm{F}$ hitung sebesar 19, 964 dengan tingkat signifikansi 0,000 dan F tabel dengan $\mathrm{dk}$ pembilang $=\mathrm{k}$ dan $\mathrm{dk}$ penyebut $(\mathrm{n}-\mathrm{k}-1)$. Jadi $\mathrm{dk}$ pembilang $=2 \mathrm{dan} \mathrm{dk}$ penyebut $=25-2-1=22$. Dengan taraf kesalahan sebesar 5\%, maka harga $\mathrm{F}$ tabel sebesar= 3,44. Dengan demikian, F hitung $(3,44)>$ dari pada $\mathrm{F}$ tabel $(3,44)$ berarti signifikan. Sehingga dapat dapat disimpulkan bahwa ada pengaruh yang signifikan antara Motivasi dan Kepuasan Kerja Pegawai terhadap kualitas layanan administrasi akademik FTIK IAIN Palu. Sementara itu, berdasarkan hasil analisis diperoleh persamaan regresi dan tingkat signifikansi antara Motivasi dan Kepuasan Kerja Pegawai bahwa persamaan regresi variable Kepuasan kerja Pegawai $\left(\mathrm{X}_{2}\right)$ dan kualiatas layanan administrasi (Y) dengan konstanta (a) =-113.315 dan b1X1 (Motivasi Kerja) =0,594 dan $\mathrm{b}_{2} \mathrm{X}_{2}$ (Kepuasan Kerja) $=$ 2,517 adalah sebagai berikut: $\mathrm{y}=\mathrm{a}+\mathrm{b} 1 \mathrm{X} 1+\mathrm{b}_{2} \mathrm{X}_{2}=-84.538+$

14 Sugiyono, Statistika untuk Penelitian, (Cet. XXIX; Bandung: Alfabeta, 2017), 231-232. 
0,672. Hal ini menunjukkan jika motivasi, kepuasan kerja meningkat satu satuan maka kualitas layanan administrasi akan mengalami kenaikan pula. Artinya, semakin tinggi kepuasan kerja maka kualitas layanan administrasi akan semakin baik.

\section{Penutup}

Dengan asumsi bahwa semua variabel lain di luar model yang dikendalikan, maka kesimpulan penelitian ini adalah sebagai berikut:

1. Terdapat pengaruh yang signifikan motivasi kerja pegawai administrasi terhadap kualitas Layanan Administrasi Akademik di Fakultas Tarbiyah dan Ilmu Keguruan IAIN Palu dengan besaran pengrauh sebesar $17,4 \%$

2. Terdapat pengaruh yang signifikan Kepuasan Kerja Pegawai Terhadap Kualitas Layanan Administrasi Akademik di Fakultas Tarbiyah dan Ilmu Keguruan IAIN Palu dengan besaran pengrauh sebesar $51 \%$

3. Terdapat pengaruh yang signifikan motivasi dan tingkat kepuasan kerja Pegawai terhadap kualitas layanan administrasi akademik di Fakultas Tarbiyah dan Ilmu Keguruan IAIN Palu dengan Besaran pengaruh sebesar $80,3 \%$ 


\section{Daftar Pustaka}

Arikunto, Suharsimi Prosedur Penelitian Suatu Pendekatan Praktek, CET. XIII; Jakarta: Rineka Cipta, 2006,

Arno F, Witting, Psychology Of Learning, New york; mc. Grow Hill Book Company 2007,

As'ad. Moch. Psikologi industriyogyakarta: libery, 2003

Daft, The Penguin Dictionary Of Psychology, Ringwood Victoria; Penguin Books Australia ltd, 2002

Hasibuan , sp, manajemen sumber daya manusia, ed revisi, bumi aksara. jakarta; 2008

Kartono. Kartini, pengantar metodologi riset sosial bandung : mandar maju, 2007,

Kotler.Philip, Marketing Management. Millennium Edition. New Jersey: Prentice-Hall International, Inc, 2000

Kottler, Philip Strategis Marketing For Educational Institution, New Jersey: Prentice-Hall International, Inc, 2000

Kreitner, Robert Dan Angelo Kinicki, Perilaku Organisasi. Jakarta: Salemba Empat 2007

Kumpulan Artikel Hasil Penelitian Bisnis dan Jurnal Strategic, Manajemen Bisnis Berbasis Hasil Penelitian, Cet; 1, Bandung: Alfabeta, 2007

L, Berry, dan Parasuraman. MarketingService Competing Through Quality. New York: The Free Press. 2002

Linn, R. L. Educational Measurement Cet.IV; New York: Mc Millan Publishers, 2006, 106.

Luthans, Fred., Perilaku organisasi 10th. Edisi indonesia. Yogyakarta: Penerbit Andi Offiset, 2006

Martoyo, Susilo Prilaku Oraganisansi, Jakarta; Rineka Cipta, 2008 .

Muchlas M, Organisasi 1 , Organizational Behavior, Jogjakarta; Ugm , 2006 
Rivai, Veithzal. Manajemen sumber daya manusia untuk perusahaan. Jakarta;PT Raja Grafindo Persada, 2004

Siagian,Sugi,Manajamen Sumber Daya Manusia. Jakarta; Bumi Aksara: 2006

Stephen, Robbin, Perilaku Organisasi, Konsep, KontroversiAplikasi. jilid 2 edisi Bahasa Indonesia Jakarta : Prenhallindo, 2003

Sugiono , Statistika Untuk Penelitian Cet. Xvi; Bandung: Alfabeta, 2010,

------------, Metode Penelitian Pendidikan, Pendekatan Kuantitatif, Kualitatif Dan RND, Bandung, Alfa Beta, 2014

Suharto Dan Budi Cahyono,Pengaruh Budaya Organisasi, Kepemimpinan Dan Motivasi Kerja Terhadap Kinerja Sumber Daya Manusia, vol. 1, no.1, Semarang: Jrbi, 2005

Tjiptono, Fandy ,Perpektif Manajemen dan Pemasaran Kontemporer, Yogyakarta: Andi, 2 